\title{
Notes
}

\section{On the Topic of Participation in the Divine Essence According to St Symeon the New Theologian in the Patristic Context}

\author{
Dmitry Biriukov
}

Research Nuclear University MEPhI, Moscow, Russia; Saint Petersburg State

University of Aerospace Instrumentation, Saint Petersburg, Russia;

The University of Padua, Padua, Italia

dbirjuk@gmail.com

Scholars often draw attention to St Symeon the New Theologian's usage of non-systematic and unconventional theological language. Such peculiarities are in evidence within St Symeon's teaching on the topic of participation in the divine substance as part of his depiction of deification.

In general, St Symeon speaks of the divine substance as being beyond all, ${ }^{1}$ although present in and filling everything. ${ }^{2}$ Borrowing the terminology of Dionysius the Areopagite, St Symeon calls the divine substance supra-substantial. ${ }^{3}$

* The author is very grateful to Mark Porter and Elena Chepel for improving his English. The present study is a part of a larger project No 15-03-00665, "Varieties of Humanism and its Trends: The Intellectual Legacy of Late Byzantium, Thirteenth to Fourteenth Centuries", implemented with a financial support of the Russian Foundation for Humanities.

1 Hymnes 30.30-32 (Symeon der Neue Theologe, Hymnen, prolegomena und krit. Text, besorgt A. von Kambyles, Berlin, 1976, S. 267).

2 Hymnes 23.186-194 (Symeon der Neue Theologe, Hymnen, ed. Kambyles, p. 201).

3 Hymnes 31.6; 47.36; 52.21-24, 46 (Symeon der Neue Theologe, Hymnen, ed. Kambyles, pp. 288; $382 ; 414,415)$. 
At the same time, St Symeon systematically describes the uniting of Christians to God in terms of participation in the divine substance. ${ }^{4}$

In his article dedicated to the usage of the notion of a substance by St Symeon, Archbishop Basil (Krivochéine) speaks of participation in the divine substance as a topic that is both highly typical of St Symeon and which at the same time represents the inconsistency of his theological language. According to Krivochéine, this inconsistency is manifested in the fact that although in Ethical discourses 3.80-82 and Hymnes 7.30-36 St Symeon speaks of Christians' participation in the divine substance as they are united to God, in Hymnes 1.26-29 and 50.198-202 he claims that deification occurs not by substance, but by participation, thereby denying his assertion of the possibility of participating in the divine substance. ${ }^{5}$ Krivochéine emphasizes that when in Hymns 50.198-202 St Symeon writes about deification by participation and not by substance, it forms one of the criteria of Orthodoxy. ${ }^{6}$ Hieromonk Alexander (Golitzin) follows Archbishop Basil regarding St Symeon's inconsistency on this topic. ${ }^{7}$

These are the fragments where, according to Krivochéine and Golitzin, St Symeon rejects the possibility of Christian participation in the divine substance:

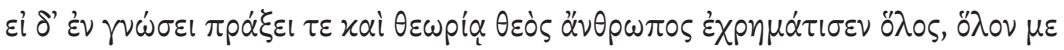

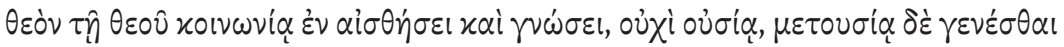

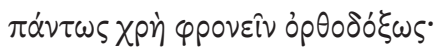

If God became entirely man - in knowledge, deed, and contemplation, that I become entirely God by communion with God, in sensation and

4 Ethical discourses 1.3.82-86 (Syméon le Nouveau Théologien, Traités théologiques et éthiques, introd., texte crit., trad. fr. et notes par J. Darrouzès, t. 1 (sc, 122), Paris, 1967, p. 202); Hymnes 7.30-36; 50.153-154 (Symeon der Neue Theologe, Hymnen, ed. Kambyles, pp. 71; 401) etc.

5 B. Krivochéine, “«Essence crée» et «Essence divine» dans la théologie spirituelle de St Syméon le Nouveau Théologien," Messager de l'exarchat du patriarche russe en Europe occidentale, 75-76 (1971), pp. 168-170 (151-170); B. Krivochéine, Dans la lumière du Christ. St Syméon le Nouveau Théologien 949-1022. Vie - Spiritualité - Doctrine, Chevetogne, 1980, pp. 206-207.

6 Krivochéine, “«Essence crée» et «Essence divine»," p. 164.

7 A. Golitzin, Symeon the New Theologian On the Mystical Life: The Ethical Discourses, vol. 3: Life. Times and Theology, Crestwood, N. Y., 1997, p. 137-138. В. Lourié, “Луч света в темном веке: Симеон Новый Богослов и догматика византийских Dark Ages [A Light Ray in a Dark Age: Symeon the New Theologian and the Dogmatics of the Byzantine Dark Ages]," EINAI: The Problems of Philosophy and Theology, 4 (1/2) (2015), <http://einai.ru/PDF/2015-04-Lurie.pdf>, also considers Symeon's concept of participation in the divine substance to be "strange." 
knowledge, not by essence, however, but by participation, as one must believe in order to be Orthodox. ${ }^{8}$

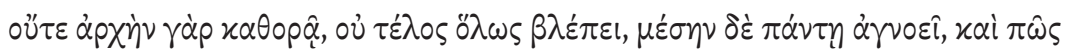

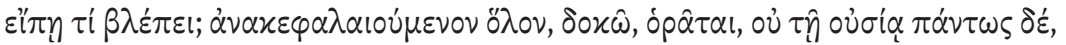
$\dot{\alpha} \lambda \dot{\alpha} \tau \hat{\eta} \mu \varepsilon \tau 0 v \sigma i \alpha$.

A human mind neither comprehends beginning, nor sees any end, nor grasps medium in Divinity, and how can it narrate what it sees? I hold that the vision is seen as total, not in essence though, but in participation. ${ }^{9}$

Thus, while relying on these fragments, Archbishop Basil and Hieromonk Alexander find a contradiction between the two lines in St Symeon: firstly, the line expressing deification in terms of participation in the divine substance, and secondly, the line which speaks of the uniting of a human being to divinity by participation and not by substance.

In turn, in his article on St Symeon's theology of the divine substance Istvan Perczel corrects Krivochéine's conclusion. Perczel examines the fragments of St Symeon's works which Krivochéine finds to be contradictory. Perczel interprets the fragments in such a way that they do not evidence anything opposite to St Symeon's words on the participation of saints in the divine substance. For Perczel the fragments deal not with divine but with human substance, i.e., they tell us that a human being is unable to become God according to his human substance. ${ }^{10}$ Thus, according to Perczel, there is no contradiction between the line which talks of deification in terms of participation in the divine substance and the text of the fragments.

I think that Perczel's conclusion is right. However, despite this, I disagree with Perczel's interpretation of Hymnes 1.26-29, since here the opposition of by participation - by substance points not to a human substance, as Perczel assumes, but to the divine substance, which, as St Symeon here teaches, is not

8 Hymnes 50.198-202 (Symeon der Neue Theologe, Hymnen, ed. Kambyles, p. 402).

9 Hymnes 1.26-29 (Symeon der Neue Theologe, Hymnen, ed. Kambyles, p. 46).

10 «...The contradiction seems only apparent. In my interpretation, here Symeon does not say that the participation is not in the very Substance of God - this would be a plain denial of what he affirms elsewhere - but only that it is not in our own substance that we become divine, or become united to God, or see Him, but only in participation - evidently in His Substance. What Symeon states here is only that the created nature never becomes God substantially, just as God has never become man according to His substance (but only in the Son's Person)» (I. Perczel, "Saint Symeon the New Theologian and the Theology of the Divine Substance," Acta Antiqua Academiae Scientiarum Hungaricae, 41 (2001), p. $\left.125^{-146}(137)\right)$. 
comprehended by the human mind even if God is seen in his totality. Nonetheless, this does not provide evidence in favour of the viewpoint of Archbishop Basil and Hieromonk Alexander: firstly because the point being made is the inability of the human mind to grasp the divine substance rather then to participate in it; and secondly (in this respect I would like to correct the position of Perczel), because in Byzantine Patristics the very opposition of by participation - by substance, even in the case of the divine substance, does not contradict the concept of participation in the divine substance. It results from a pervasive Patristic view regarding the notions of participation and substance which I will speak about below.

But first, I would like to introduce some additional fragments by St Simeon relevant to the topic of participation.

In the writings of the New Theologian we can find further discussion of the uniting of a human being to God by participation in relation to a symbolic understanding of light. Symeon writes in his 7 th Ethical discourse:

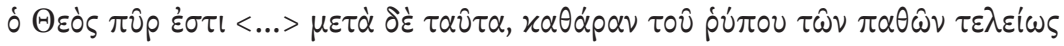

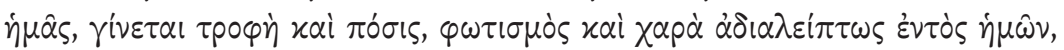

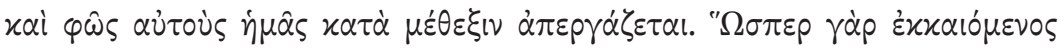

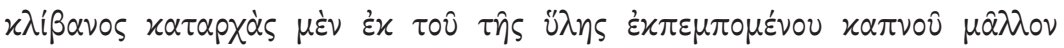

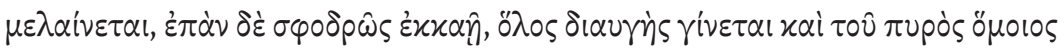

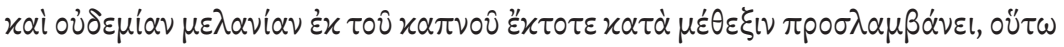

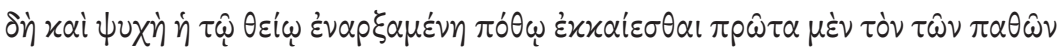

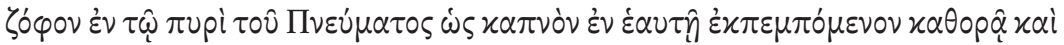

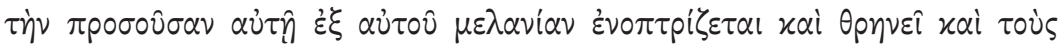

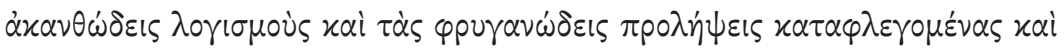

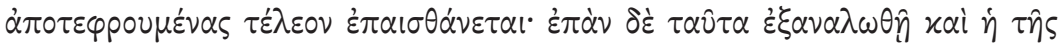

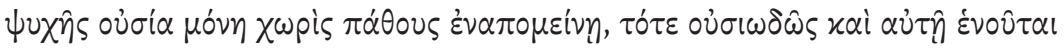

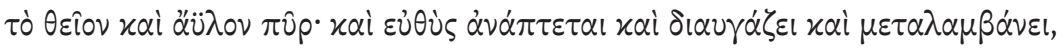

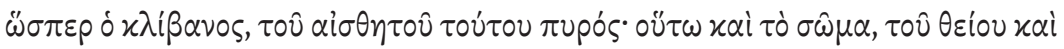

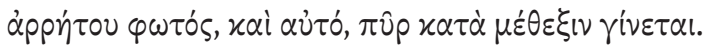

God is a fire ... When it has completely cleansed us of the filth of the passions, it becomes food and drink, light and joy without ceasing within us, and, by participation, it makes us light ourselves. It is like a clay pot that has been set on the fire. At first it is somewhat blackened by the smoke of the burning fuel, but after the fuel has begun to bum fiercely, then it becomes all translucent and like the fire itself, and the smoke can communicate none of its blackness to it. Just so, indeed, does the soul which has begun to burn with divine longing see first of all the murk of the passions within it, billowing out like smoke in the fire of the Holy Spirit. ... After 
these things have been utterly destroyed and the essence alone of the soul remains, quite without passion, then the divine and immaterial fire unites itself essentially to the soul, too, and the latter is immediately kindled and becomes transparent, and shares in it like the clay pot does in the visible fire. So, too, with the body. It, too, becomes fire by participation in the divine and ineffable light. ${ }^{11}$

St Symeon here depicts the way in which the human being is united to God by participation in relation to the human soul and body. As the New Theologian points out, the soul and body of people freed from passions become by participation that which God is, namely, Divine Fire and Light, ${ }^{12}$ and this represents the essential uniting of a human soul to Divine Fire/Light. The notion of by participation ( $\varkappa \alpha \tau \dot{\alpha} \mu \dot{\varepsilon} \theta \varepsilon \xi(v)$ factually acts as a term here. One can say that St Symeon sets that which is by participation (the fire of a passionless soul and of a respective body) in opposition to that which is participated in, i. e. the selfexistent (the Divine Light and Fire participated in by the souls and bodies of saints).

We can supplement the afore-cited fragment with an extract from the 33rd Catechetical discourse:

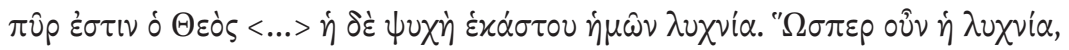

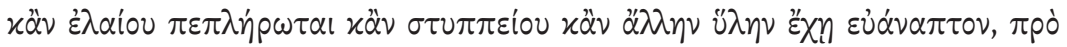

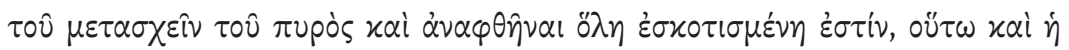

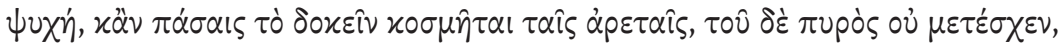

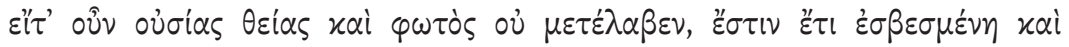

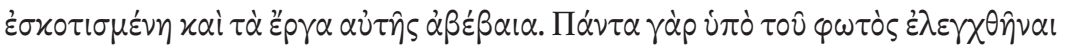

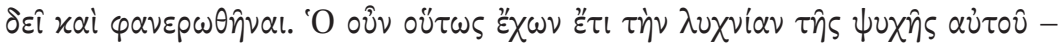

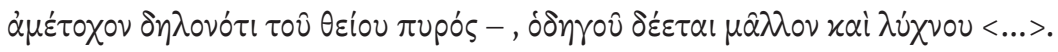

God is Fire $\langle\ldots .$. . And the soul of each of us is a lamp. And so, just as the lamp remains completely darkened before it participates in the fire being kindled, even if it is full of oil or tow or some other flammable matter, so also the soul, even if it is decorated, as it seems, with all virtues but does not participate in the Fire, and therefore does not take part in the divine

$11 \quad$ Ethical discourses 7.509-536 (Syméon le Nouveau Théologien, Traités théologiques et éthiques, introd., texte crit., trad. fr. et notes par J. Darrouzès, t. 2 (sc, 129), Paris, 1967, pp. 192-194), transl. by A. Golitzin, in: Symeon the New Theologian, On the Mystical Life: the Ethical Discourses, Crestwood, NY, 1996, pp. 98-99. same denotation. 
essence and light, is still extinguished and darkened and its deeds are unsteady. For everything should be examined and revealed by the Light. And so, if the lamp of one's soul is still in such a state, that is, non-participating in the divine fire, that person needs a guide and a lamp $<\ldots . . .^{13}$

Here participation in Divine Fire and Light is equated with participation in the divine substance. Therefore, one can say that when St Symeon speaks of the uniting of Christians to God (= Divine Light/Fire) by participation, it means participation in that which God is according to His substance.

Thus, these fragments shows us how the twin concepts of by substance / by participation, although not expressed as an explicit opposition, were used by St Symeon when he spoke of unity with God as participation in Divine Fire/Light understood in the sense of the divine substance.

Now, I will briefly outline the Patristic context of the topic of participation in the divine substance as well as the opposition of by substance / by participation, in connection with St Symeon's teaching.

Archbishop Basil does not raise the question of the sources of patristic influence on St Symeon's doctrine of participation in the divine substance, pointing out only the Second Epistle of Peter. ${ }^{14}$ Istvan Perczel, on the other hand, does wonder about this topic. Perczel rightly makes reference, firstly, to 2 Pet 1:3-4, secondly, within Patristic literature - to the writings of Makary/ Symeon of Mesopotamia, ${ }^{15}$ and, thirdly, to liturgical texts. ${ }^{16}$

Regarding the impact of Macarius/Simeon's corpus on the topic of participation in the divine substance in St Symeon, I can agree with Perczel only in the sense that we can consider it to be an important source for St Simeon in this respect. However, I do not agree that this corpus should be considered as the only possible Patristic source for this theme in St Simeon, since the concept of participation in the divine nature is frequently depicted alongside the theme of deification in Patristics.

Indeed, it can be traced back to the Second Epistle of Peter, which states that

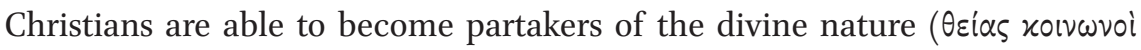

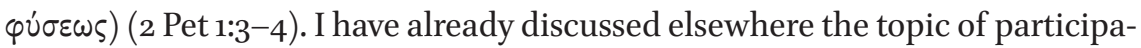
tion in the divine substance (nature). ${ }^{17}$ This topic - with implicitly or explicitly

13 Catechetical discourses 33.8-19 (Syméon le Nouveau Théologien, Catéchèses, introd., texte critique et notes par B. Krivochéine, J. Paramelle, t. 3 (sc, 113), Paris, 1965, pp. 248-250).

14 Krivochéine, "«Essence crée» et «Essence divine»," p. 164.

15 II, 39, 9-11; II, 15, 36, 539-547.

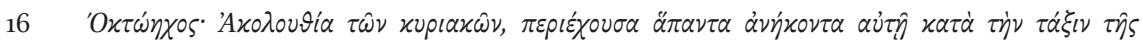

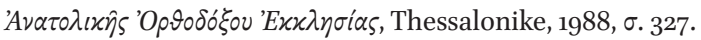

D. Biriukov, "Hierarchies of Beings in the Patristic Thought: Maximus the Confessor, John of Damascus and the Palamite literature," in: Scr, 10: Syrians and the Others: Cultures of the 
opposition to possession of it, and allusion to 2 Pet 1:3-4 - was used in the early Byzantine literature by Athanasius of Alexandria, ${ }^{18}$ Gregory of Nyssa, Cyril of Alexandria, Macarius the Great ${ }^{19}$ and other authors. In Middle Byzantine literature it was dealt with by John of Damascus ${ }^{20}$ and by Symeon the New Theologian. ${ }^{21}$ Within this trend in Patristic literature writers argue that holy people participate in the divine substance, but, unlike hypostases of the Trinity, do not possess it. Accordingly, I suggest that this is a commonplace in pre-Maximian (in the conceptual, not temporal sense) theological language. Evidently Perczel was not aware of this when he stated: "...As concerns Gregory the Theologian, the other Cappadocians $\langle\ldots\rangle$ they $<\ldots>$ could hardly be the origin of the latter's [St Symeon's. - D. B.] doctrine of a substantial participation [in God])."22

In Byzantine Patristic literature this paradigm of participation receded into the background with the appearance of the new philosophical language found in the Corpus Areopagiticum. Those notions, which earlier Patristic exegesis expressed through the opposition of by existence (by nature) - by participation, started to be expressed within a Dionysian philosophical and theological framework through the conceptual triad of non-participated - participated participating which was adopted by the author of the Corpus Areopagiticum from Proclus. In the process of transferring this triad into Christian theological thought, the Areopagite makes a distinction in the divinity between the par-

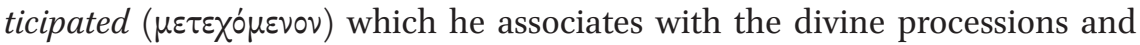
powers, and the non-participated ( $\dot{\alpha} \mu \varepsilon \dot{\theta} \varepsilon \kappa \tau \circ \varsigma)$ - the supra-substantial divinity of God. ${ }^{23}$ The author of the scholia to the Corpus Areopagiticum interprets this in such a way that while divinity can be participated in according to its proces-

Christian Orient in the Middle Ages (2014), pp. 281-304 (284-285, 292, 299-300); idem., "Hierarchies of Beings in the Patristic Thought: Gregory of Nyssa and Dionysius the Areopagite," in: The Ways of Byzantine Philosophy, ed. M. Knežević, Alhambra, CA - Kosovska Mitrovica, pp. 71-88 (75-78). For example, Epistulae quattuor ad Serapionem, in $P G$ 26, col. 585 B-C.

19 The last two authors very often devoted their attention to this subject; each of them has dozens of pertinent passages.

For example, Orationes de imaginibus tres 3.33 (Die Schriften des Johannes von Damaskos, vol. 3, ed. B. Kotter (Patristische Texte und Studien, 17), Berlin, 1975, S. 138).

Ethical Discourses 1.3.82-86 (Syméon le Nouveau Théologien, Traités théologiques et éthiques, éd. Darrouzès, t. 1, p. 202); Hymns 7.30-36; 50.153-154, 200-202 (Symeon der Neue Theologe, Hymnen, ed. Kambyles, p. 71; 401; 402-403) etc.

Perczel, "Saint Symeon the New Theologian and the Theology of the Divine Substance," p. 140, cf. 134 .

De divinis nominibus 2.5, 11.6 ( $P G$ 3, col. 644A,C, 956A-B). 
sions and energies, God can not be participated in according to His nature. ${ }^{24}$ Moreover, this paradigm assumes that He is completely unparticipated in by all created beings, including saintly people. The topic of the ultimate impossibility of participating in God by substance and the opportunity of participating in God by energies was developed in the writings of Maximus the Confessor (possibly the author of the scholia to the Corpus Areopagiticum mentioned above). ${ }^{25}$ After Maximus, the neo-Platonic participation paradigm which implied the complete impossibility of participating in God according to substance, for a time fell out of use. It later reemerged among Orthodox theologians after the rediscovery of the theological heritage of Maximus the Confessor at the end of the life of Nicetas Stethatos, that is, in the last quarter of the eleventh century. Then this paradigm was taken over by Gregory Palamas; in the course of the Palamite Controversy the idea of the possibility of created beings' participation in the divine substance was eventually rejected in the Tomos of the Council of the Church of Constantinople in $1351^{26}$ and anathematized in a special supplement to the Synodikon of Orthodoxy. ${ }^{27}$

Therefore we can say that inasmuch as St Symeon's theology talks of deification in terms of participation in the divine substance, it follows a pre-Maximian line of thought.

In Patristics the topic of participation in the divine substance is somewhat related to the opposition of by participation - by substance which also appears in the works of St Symeon.

This theme goes back to the Patristic authors of the III-IVth cc. It was outlined by Origen ${ }^{28}$ but it manifests itself most notably in St Athanasius ${ }^{29}$ and the Cappadocian Fathers ${ }^{30}$, who opposed by substance and by participation in order to maintain a distinction between the created and the divine when

$24 P G$ 4, col. 221C, 404A-B, 404D.

25 Quaestiones et dubia 173.1-7 (Maximi Confessoris Quaestiones et Dubia, ed. J.H. Declerck (CCSG, 10), Turnhout, 1982); Capita theologica et oecumenica (PG 90, col. 1180C-1181A).

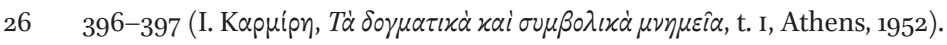

27 Synodicon of Orthodoxy 628-633 (J. Gouillard, "Le Synodikon de l'Orthodoxie. Édition et commentaire," Travaux et Mémoires, 2 (1967), p. 1-316 (85)).

28 Origen, Fragmenta in diversos Psalmos in catenis, Ps. 135 (PG 12, col. 1656A).

29 Athanasius of Alexandria, Contra gentes 46 (PG 25, col. 93BC), Epistulae quattuor ad Serapionem 2.4 ( $P G 26$, col. $613 \mathrm{C}$ ).

$30 \quad$ See for example Gregory of Nyssa, Adversus Eunomium 1.1.276.1-277.1 (Gregorii Nysseni opera. Contra Eunomium Libri I et II, ed. W. Jaeger, Leiden, 1960, p. 106), Basil of Caesarea, Adversus Eunomium 3 (PG 29, col. 66o.14-30; Gregory of Nazianzus, Oration 22.11. Cf. Cyril of Alexandria, Fragmenta in sancti Pauli epistulam ii ad Corinthios 1.2 (Sancti patris nostri 
speaking of the uniting of the first to the second, and to emphasize the status of the uncreated as such ${ }^{31}$. If we can make any generalizations about what can be found in the works of the Niceans in this regard, it is the following: created beings are deified by participation in the divine substance, without becoming God according to their substance, while the Persons of the Trinity are God by substance, not by participation (this latter point was connected with the Arian controversy relevant for the Niceans). Thus, according to the Niceans, the topic of participation in the divine substance did not exclude, but admitted the opposition of by participation - by substance, where a substance can be understood both as the substance of the created being (a human being or an angel) and as the substance of God.

Thus, in the case of the usage of the opposition of by substance - by participation in Hymnes 50.198-202, St Symeon pursues his own particular course: he teaches that a human being achieves deification and becomes God by participation, not becoming God by his substance. To my mind, the same course forms the background to his Ethical Words 7.509-536 and, to a lesser extent, his Catechetical Discourse 33.8-19. In a similar manner to the Cappadocians, St Symeon combines this opposition with the topic of participation in the divine substance, where by participation within the opposition is understood as by participation in the divine substance.

The opposition of by substance - by participation is next manifested by St Maximus the Confessor. In the 8th Questions to Thalassius Maximus answers the question: "Inasmuch as Saint John speaks that God is Light (1 John 1:5), and then: we walk in the light, as he is in the light (1 John 1:7), how come the same is both called light and is found in light" in this way:

Cyrilli archiepiscopi Alexandrini in D. Joannis evangelium, vol. 3, ed. P.E. Pusey, Oxford, 1872, p. 326.20-26).

$31 \quad$ About the opposition between by participation and by nature in Origen, Athanasius of Alexandria and the Cappadocians see D. Balás, METOYEIA @EOY. Man's Participation in God's Perfections according to St. Gregory of Nyssa, Rome, 1966, pp. 11-12, 6o-62; idem., "Participation," in: The Brill Dictionary of Gregory of Nyssa, ed. L.F. Mateo-Seco, G. Maspero, Leiden - Boston, 2010, pp. 581-587 (583); J. Finch, Sanctity as Participation in the Divine Nature According to the Ante-Nicene Eastern Fathers, Considered in the Light of Palamism, Drew University, 2002 (Ph.D. Dissertation), pp. 244, 308, 351, 380; A. Kolp, "Partakers of the Divine Nature. The Use of II Peter 1:4 by Athanasius", in: Studia Patristica 17 (1982), pp. 1018-1023 (1020-1021); K. Norman, Deification: the Content of Athanasian Soterilogy, Duke University, 1980 (PhD Thesis), p.189. See also about Cyril of Alexandria: W. Burghardt, The Image of God in Man According to Cyril of Alexandria, Washington, 1957, p. 11. 


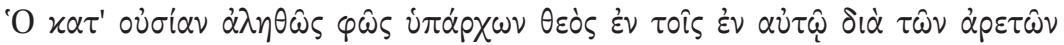

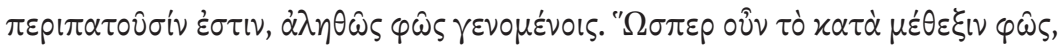

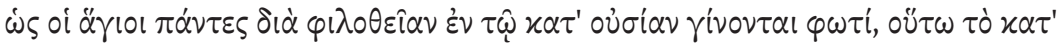

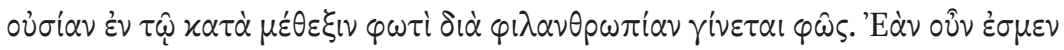

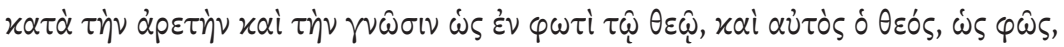

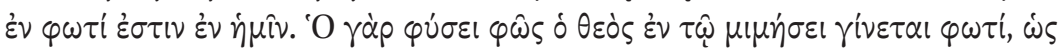

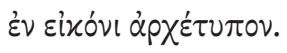

God, by essence truly being Light, truly becomes light in those who live in Him through virtues. Indeed, just like all the saints by participation dwell as the light through the love of God within the Light by essence, so also the Light by essence dwells through the love of man within the light by participation. So if we are by virtue and knowledge in the Light which is God, then God himself, as Light, is in the light which is us. For God, being Light by nature, appears in the imitation of light, like the Prototype [appears] in the image. ${ }^{32}$

As well as the Cappadocians, Maximus employs the opposition in his teaching that a human being is deified by participation, not becoming God by substance, while the uniting of a human being to God by participation happens by virtue of what God is by substance. However since the concept of participation in the divine substance was forbidden within the theological language of Maximus he, in contrast to the Cappadocians, avoids combining the opposition with the concept of participation in the divine substance.

It is worth observing that Maximus uses the symbol of light in the same manner as St Symeon, while speaking of the uniting of a human being to God by participation. Both authors depict the process by which saints are united saints to God as a process through which the saints become the Light by participation ( $\varkappa \alpha \tau \dot{\alpha} \mu \varepsilon \varepsilon \varepsilon \xi(v)$ due to uniting to what the Light is by substance. The Light grants itself to people and allows them to participate in Itself. Taking this similarity into account, it is seems hard to deny the influence of Maximus on the works of St Symeon. The theological language of the latter combines the concept of light with a depiction of unity with God by means of the category of $\varkappa \alpha \tau \dot{\alpha} \mu \varepsilon \dot{\varepsilon} \theta \varepsilon \xi$, which presupposes the opposition of the participated in with the participating.

At the same time, the two authors display important differences on this theme: St Symeon teaches about the uniting of a human being to Divine Light/

$3^{2} \quad$ Maxime le Confesseur, Questions à Thalassios, intr. et notes par J.-C. Larchet, trad. par F. Vinel (sC, 529), Paris, 2010, p. 77. 
Fire by participation, treating it as participation in the divine substance, while St Maximus, in accordance with the trend I have noticed, leaves this out, preferring not to speak explicitly of the possibility of participation in the divine substance. This can be explained by the difference noticed above in the authors' understanding of the concept of participation in the divine substance.

Thus, we come to the following conclusions:

Firstly, inasmuch as St Symeon's doctrine does not include the concept of the ultimate impossibility of participating in God by substance, his theological language pertains to the pre-Maximian epoch in Byzantine theology (in a typological sense).

Secondly, the usage of the opposition by substance - by participation by St Symeon corresponds to a normative line in Byzantine Patristic thought: a human being is united to God by participation, not becoming God by his own, human substance. In accordance with the pre-Maximian trend towards a participation paradigm, St Symeon depicts deification as that which take place by participation understood as participation in the divine substance. By virtue of this, the statement regarding the inconsistency of St Symeon's doctrine is incorrect, since in the framework of pre-Maximian theological language, which St Symeon follows, there was no contradiction between the topic of participation in the divine substance and the opposition of by participation - by substance, but these two concepts were closely related.

Thirdly, despite St Symeon following pre-Maximian theological language when he depicts deification through participation in the divine substance, we can suppose that St Maximus nevertheless influenced the specifics of St Symeon's depiction of deification as it relates to the category of participation. 